DigitALCOMMONS @WAYNESTATE-
Michigan Journal of Counseling:

Research, Theory and Practice

Volume 37 | Issue 2

Article 2

$12-1-2010$

\title{
One White Counselor Educator's Process of Racial Reeducation
}

Mary Fawcett

Winona State University, mfawcett@winona.edu

Follow this and additional works at: https://digitalcommons.wayne.edu/mijoc

\section{Recommended Citation}

Fawcett, M. (2010). One White Counselor Educator's Process of Racial Reeducation, Michigan Journal of Counseling, 37(2), 4-12. doi: $10.22237 / \mathrm{mijoc} / 1291161660$

This Article is brought to you for free and open access by the Open Access Journals at DigitalCommons@WayneState. It has been accepted for inclusion in Michigan Journal of Counseling: Research, Theory and Practice by an authorized editor of DigitalCommons@WayneState. 


\section{One White Counselor Educator's Process of Racial Reeducation}

\section{Mary Fawcett}

\section{Winona State University}

\section{Abstract}

Counselor educators introduce racial/cultural identity models in order for students to examine their own racial identity and learn the value of identifying the stage of racial/cultural identity development of their clients. While there is an abundance of literature about the multicultural training of White students, there is very little on training experiences of White counselor educators. It is by focusing on the competency training of White counselor educators that we can determine the cultural competence of trainees. I am a White woman that was raised in a racist community in the 1970's and trained as licensed professional counselor during the 1980's. Through this article, I describe my journey as a developing counselor and educator: mistakes made, struggles overcome and recent experiences that contribute to my increased effectiveness in classroom, advocacy and social justice activities.

Key words: multicultural, training, racial identity

\section{One White Counselor Educator's Process of Racial Reeducation}

A positive racial identity is the ability to appreciate one's own race/ culture without making judgments about its superiority over that of others (Helms, 1984). I have struggled to teach White counselor education students to 1 ) believe that examining their race/culture is important; 2 ) think that they need to do more than simply learn about others' cultural/racial communities, religions, and history, to be multiculturally effective; and 3) commit to lifelong social justice efforts. I thought for many years that I was just dealing with a particularly tough group of students when I realized the problem was not my students, but me. The combination of my upbringing in a racist family and community, and a multiculturally-lacking early masters' training program made it very difficult to understand the importance continuing education on the topics of post culture and diversity. My doctoral program was my first exposure to African American professors, diverse clients and courses in multicultural counseling competency and racial/cultural identity theory. I know my early masters' training was not atypical when I read about Arredondo's (1999) concern that counselor training typically required only one course in multicultural counseling. I also find less shame about my early negative attitudes when I read D'Andrea and Daniels $(1999,2001)$ findings' during their 16 years of White racism research that common reactions of White counselor educators, practitioners, and graduate students included:

Dr. Mary Fawcett is an associate professor at Winona State University in Winona, Minnesota. She can be contacted at: mfawcett@winona.edu 
-anger in having to deal with political correctness

-generalized apathy towards the subject of culture and diversity in general)

-intellectual detachment from their knowledge about societal oppression by taking no action for positive change.

I now know my students were simply reflecting my attitude about cultural and diversity course content by doing the assignments as if they were just completing another assignment.

Despite the development of cross-cultural training models that include exploration of counselor as a cultural being (e.g. Johnson, 1987; Carter, 1995), researchers have found most multicultural training approaches emphasize students' focused research on a cultural group different from their own (Carter, 2003; Utsey, Gernat \& Bolden, 2002). It makes sense to me now the ways in which I developed and implemented training models that today reflect most multicultural training approaches. I find it interesting that this focus on other cultures runs counter to the first Multicultural Counseling Competency (MCC; Arredondo, et al., 1996) in which students study their own cultural values, biases and worldview, and have committed to adapting my current training model to include more self-examination by my students. Through this process of redefining my goals in multicultural education, I realized I needed more self-exploration about my own racial identity. Through my racial identity exploration I noticed a parallel process my students were experiencing in terms of new discoveries about their racial identity. Together, as we were each discovering our past racial experiences and current identity development, I found it inspiring to watch my students and I struggle with similar challenges. Additionally, I found my honesty about my process developed a level of mutual trust in our discussions about our biases and how these attitudes would permeate the counseling process in negative ways if we did not address our issues. When I had the realization that I needed self-exploration I was not surprised to find as I developed my own racial identity, I became more effective in training my students to be more culturally competent.

\section{Discussion}

I have struggled for years to find the appropriate metaphor for what counselors need to go through to achieve what Janet Helms (1992) calls "reeducation" of how we look at equality and become aware of our own racist tendencies and blind spots. The parallel experience for me is learning Spanish. I want to be bilingual and have been a vigilant student for over four years. I also desired to be non-racist and learned how to self-reflect, study multicultural counseling with better comprehension, and apply cultural identity developmental tasks to my everyday living. When I put into words how I struggle with my "re -education" of a racist perspective I realize I have the same difficulty in describing the challenges of learning a new language. This process of putting into concrete terms what exactly my struggle is allows me to determine the next step in my journey. I realize I have two important and significantly difficult goals 
in becoming bilingual and non-racist. I realize I will fail at both because I will never be as fluent in Spanish as I wish to be (I simply started studying too late in life), and I will never be as non-racist as I hope to be (I live in a culture that reinforces racism on many levels). However, as long as I keep trying to achieve these goals, I am not allowing the current climate to continue to condition me to give up on my bilingual and non-racist identity goals. If I do not study Spanish with daily tenacity, I forget vocabulary and sentence construction very quickly; if I do not focus my attention on the many continuous incoming daily racist messages through my community and the media, I lose ground on my still fragile non-racist identity. So I practice new Spanish words as I move about my day (e.g., when I see my dog, I say "perro") and I practice non-racist acts during conversations with family, friends, colleagues and students by confronting them on the ways in which they say things or pointing out a joke that denigrates another race. By doing these things, I build a wider bilingual vocabulary and am able to filter out racist messages. I also continue to become aware of ways in which my world reinforces racist ways of doing things. So, learning a new language is like learning to be non-racist for me: I will always speak English better than Spanish, and I will be better at being racist than non-racist. The paradox is that the more I realize I am racist, the more multiculturally competent I become as a counselor educator. I am working on ways to work against my 'grain' and accept these realities and work for social justice in my own life and pass these lessons onto my students.

\section{Racist Lessons}

I was raised in a home with culture and gender biased role models. My grandparents were explicitly racist people who were very vocal about their beliefs. My parents were implicitly racist and I think they believed they were achieving non-racist status in comparison to their parents. What I know now is that they taught me an insidious form of racism that is more dangerous than the type my grandparents exhibited. I learned my parents' style of racism well because it was reinforced in all the communities in which I have lived.

In my youth and on into college, I bought into the belief that if I was 'color blind' I was showing myself to be trustworthy of equal relationships with anyone from any culture or income level. While I was taught to not see skin color in a person, the first thing I noticed when meeting others were the differences (skin color, hair type, facial structure, etc.). I also noticed the cultural accent or English slang used, and the fear and mistrust of me as a White person. I didn't admit my observations because I had never heard anyone else in my "community" of family or friends mention these things and I wanted to fit into my social group. I saw how my family and friends made fun of people who were different. If I was to disagree with anyone about racist ideas, I was shunned. Nowadays, I care little about this reaction from others but I still recognize the looks on people's faces when I try to 're-educate' them. It is not a welcoming, curious look. It is a look that says "what language are you speaking?".

\section{Racial Identity Development}

As I move through my own racial development I realize I have really 
never completely transitioned from "abandoning my racism" to developing a "non-racist" identity, a process Helms (1992) describes as the two-phase process to a healthy White identity, but I have made great strides in working toward my goal of becoming less racist. I have been slowly advancing toward nonracist status since 2002 when I began to focus my professional development and research on multicultural counseling competency. My greatest progress was in 2007, when one of my graduate students recommended I read Lies My Teacher Told Me, Everything Your History Teacher Got Wrong (Loewen, 2007). I felt alternately sickened and empowered as I read about the accurate histories (and the concrete evidence of such events) about White oppression beginning with the colonists who arrived in the New World. Sickened because I felt the racial identity stage of Immersion-Emersion that Helms describes as the stage in which "the person assumes personal responsibility for racism and develops a realistic awareness of the assets and deficits of being white" (1992, p. 33). Empowered because in the Immersion-Emersion stage I was beginning to explicitly confront racism in my social group and developing a humanitarian attitude towards all people by learning the accurate contributions of all people in the development of the North America I know.

My gift to myself during this tumultuous time was to realize I could choose to unlearn the history that was fed to me in my secondary school experiences. I reeducated myself about North American history by reading biographies of people from all racial and cultural groups who contributed to the growth and development of the United States. I attempted to re-educate my friends and family (an ongoing project). I also realized I did not have to act on the conditioned racist thoughts in my mind that were planted in my childhood. I believe (and currently teach my students) that racist thoughts are like a recording they will always be there, but we can choose to turn down the volume or select to not listen to them.

In my 12 years as a counselor educator, I have taught in a very similar fashion to how I was taught while a graduate student. Since I work at a Midwest university in a predominantly White population, it is relatively easy to teach my students how to work with White clients and 'mention' race and culture as a second thought. I felt embarrassed the first time I realized I was teaching $90 \%$ of a counseling theories course on the traditional "dead White man's theories" and, at best, $10 \%$ on multicultural theory. I felt shame when I realized I had prioritized outdated lectures over new multicultural material when pushed for time (because it is easiest to go with what is familiar in a time crunch). When I assigned mock counseling sessions, we hardly ever role-played counseling sessions dealing with cultural differences between counselor and client.

My professional challenges include mishandling difficult discussions about race in my classrooms, ignoring students' rude comments about learning multicultural counseling course content (e.g. "I just don't have the time to learn all this"), and doing little with the multicultural research I conducted other than publishing the data. I began to improve my instruction as I moved from Helm's status of Pseudo Independence to the Emerson status. Incorporating activism in my personal life meant meeting my professional challenges with more courage 
and I found myself able to address the aforementioned difficult discussions.

\section{Instructor Competence}

In 2005 I began my study of the Spanish language. I had been doing career counseling with students from Mexico and Central America and practicing my Spanish in the process. About the same time, I had been seriously considering a cultural immersion experience in Central America but could find no one to share the journey with me. Out of fear of travelling alone, I put off my plans until I met a colleague who wanted to join me in my cultural immersion in Guatemala. In 2007, with my colleague, I travelled to Antigua, Guatemala to study Spanish and experience immersion in a culture unlike my own. Part of my motivation for this experience was to understand better my Latino/a students' simultaneous appreciation for their secondary education and apathy in furthering their education once they graduated. I could not comprehend the fact that these students were not sharing my White person's value for "education above all else" and I had no effect in my attempts to motivate them to change their belief system.

I had never been out of the United States and certainly never viewed third world poverty up close. I still cannot describe in words the beginning of my personal and professional transformation when I first visited Guatemala, nor can I express the profound sense of being when I return annually. What I can describe are some of the most difficult elements of this experience: physically painful homesickness, shameful inability to speak the language despite my most earnest attempts, awkward self-consciousness about my height and skin color, extreme fear I had about the unknown, maddening frustration during a moment at a bank when the tellers kept me waiting while determining amongst each other whether my travelers' check was valid, fearful shock in seeing armed (semi-automatic weapons) tour guides and policeman, and heart wrenching sadness during moments visiting with and watching four and five-year old children selling jewelry or shining shoes in the parks and streets of Antigua.

I found that the most common mode of income for Guatemalan and Mayan families is money sent from family members working in the US. I was also made aware of the lack of access to clean water in Guatemala. (I realized at home after my first visit that I use more clean water in one shower than most Guatemala and Mayan families have access to in a month.) Additionally, I found most Guatemalan and Mayan families live within their community of extended family members and work together to sustain themselves. Finally, I observed these amazing people experience joy in their lives on a daily basis despite the sad reality of the poverty in which they live.

I can describe my time in Guatemala as an experience of being exactly where I needed to be at the time for many reasons. When I return, I receive validation that I am not only doing something important to bring resources to people who are desperately in need, I am also learning something of value about my level of multicultural competence as a person and educator. Mostly, I learn that it will always be a challenge to understand another person's experience. I can feel deep compassion and respect and awe for the Guatemalan and Mayan 
people I met while travelling, but I absolutely felt limits in understanding their experience. I think it is important for me to acknowledge that every time I return to Guatemala, I get a deeper sense of the way my racist upbringing continues to affect my attempts to be non-racist (even though I oftentimes cannot put it into words). Because of this renewed knowing, I am not surprised how hard I have to work to rise above my own limiting experiences, but find that time spent in Guatemala helps me become a little more culturally aware on several levels. Hanley (2005) states that ones' experiences limit their perspective. As I experience more unique moments in another culture, I realize my perspective about my (White) place in the world changes to a more accurate picture of reality. My reality is that I will always be working toward a non-racist identity and the shedding of many years of inappropriate education I received both formally and informally. As I continue to be aware of the white privilege I have been afforded in my life, I realize I can undo twenty-five years of racist conditioning, a little at a time. As I reeducate myself on multicultural counseling competency development and counselor education, I become more likely to live and work from a less racial stance.

Back home, I finally began to appreciate my Latino/a students' immigration experiences. I can empathize more easily when they tell me about the excruciating discomfort they have experienced being in an unwelcoming and foreign place, and the aching of one's soul when separated from loved ones. I appreciate their discomfort in sitting in a classroom and struggling to understand the teacher's language. I appreciate the attempts that some of my students make to "pass" for White. When I share about my travels to Antigua, I find my students more willing to discuss with me their stories about how they came to live in the US. Some of these immigrants came here illegally and risked life and limb while travelling with their family. Others came to this country legally but had to leave family behind. Some of these students were born in the US and worked full-time at jobs while attending school while others had to quit school to work two or three jobs to take care of their parents who had immigrated to the US but remained monolingual and worked on farms and in factories. Post Guatemala, my work with these students continues but I am a better career counselor for them in that I stopped trying to push my agenda of post-secondary education, stayed out of their way, and watched them set realistic and valuable goals for their future. I became a culturally effective counselor and, in turn, am able to be a more culturally effective counselor educator.

Robinson (1999) states that 'it is rare that a White person has an experience that focuses them to assess their attitudes about being a racial being" ( $p$. 88). I have realized to move meaningfully and intentionally to a non-racist identity I must experience something outside my world on a regular basis and have decided to continue these experiences in Guatemala and other parts of the world. I have gained the realization that the more we realize about the little we know about other cultures, the more likely we are to develop cultural competency. While I can be compassionate and useful in some ways as a counselor and educator, I think the real value in diversity experiences for me is the stark reality that I cannot be "totally" culturally competent and this is a life-long quest. This 
does not make me incapable of working with diverse others or teaching students how to work with diverse others. What this does mean is that I need to stay vigilant about the ways in which I am not competent as a counselor educator and teach my students to do the same in their quest for a healthy racial/ cultural identity and multicultural counseling competence.

After a recent extensive review of counseling literature, and ten years of conversations with colleagues, I now believe counselor educators are universally poorly trained on how to educate their students how to be culturally effective. I also believe our counseling profession uses rhetoric about cultural diversity and social justice issues to "appear" to be working to answer the professional charge to develop multicultural competencies and social justice skills. I believe we all need to be held accountable for actually doing a better job at teaching and measuring competence. For example, I have conducted pre/post quantitative studies on multicultural competency in a travel immersion course and relied on self-assessment instruments. I thought I had done an excellent job of providing support for other studies in my profession. What I now realize is that I need to do more to measure implicit bias using a non-subjective measurement tool. This type of research is more time consuming, but I believe a serious, valuable journey to cultural effectiveness demands the commitment required of more effective research practices.

My on-going challenge at this time in my career is to begin to be more intentional in my instruction, more courageous in addressing uncomfortable conversations in my classrooms, and more determined to continue to not let my racist conditioning interfere with my growth of a healthy White identity. Some of the ways in which I feel I am working on the second phase of developing a nonracist White identity are to be more vigilant about my own continued study of multicultural professional literature by following my younger colleagues' examples of making time to delve into new research and multicultural literature on a regular basis. I am also finding new methods of integrating multicultural counseling theory in a counseling theories course, requiring my students to do a meaningful cultural immersion experiences in every class I teach. I am maintaining the integration of popular literature such Nickel and Dimed: On Not Getting By in America (Ehrenreich, 2002) in my course assignments, and finding more meaningful ways in which to teach my students how to measure their cultural effectiveness.

\section{Conclusion}

"It is easy to ignore what you neither feel nor understand" (Hanley, 2005, p. vi). The author shares her journey from ignorance about cultural issues to an awakening of humility as she works her way to what Helms (1992) calls an evolution of a non-racist identity. Her continued work is to take notice of times in which she is abandoning racist thoughts and tendencies in favor of developing a healthy racial identity in order to more effectively teach her students how to use current racial/cultural identity models to become culturally effective counselors. Unlike some authors who believe we can undo racism, she believes we cannot undo what has been reinforced for centuries through 
insidious and dysfunctional cultural beliefs about equality among people from all races and cultures. However, she trusts that we can continue to become aware of our racist thoughts and tendencies and not allow them to affect our work by taking the leap to visit other communities and cultures, learn new languages and literally put ourselves in a foreign experience. Only by moving outside our own comfort zone can we begin to lose White arrogance and situate ourselves as lifelong learners in non-racist ways of being.

\section{References}

Arredondo, P., Toporek, R., Brown, S. P., Sanchez, J., Locke, D. C., Sanchez, J., Stadler, H. (1996). Operationalization of the Multicultural Counseling Competencies. Journal of Multicultural Counseling \& Development, 24(1), 42-78.

Arredondo, P. (1999). Multicultural counseling competencies as tools to address oppression and racism. Journal of Counseling and Development, 77, 102108.

Carter, R. T. (1995). The influence of race and racial identity in psychotherapy: Toward a racially inclusive model. New York: Wiley.

Carter, R. T. (2003). Becoming racially and culturally competency: The RacialCultural Counseling Laboratory. Journal of Multicultural Counseling and Development, 31, 20-30.

D'Andrea, M., \& Daniels, J. (1999). Exploring the psychology of White racism through naturalistic inquiry. Journal of Counseling and Development, 77, 93101.

D'Andrea, M., \& Daniels, J. (2001). Expanding our thinking about White racism: Facing the challenge of multicultural counseling in the $21^{\text {st }}$ century. In J. G. Ponterotto, J. M. Cassas, L. A. Suzuki, \& C. M. Alexander (Eds.), Handbook of multicultural counseling (pp. 289-310). Thousand Oaks, CA: Sage.

Ehrenreich, B. (2002). Nickel and dimed: on (not) getting by in America. New York: Henry Holt and Company.

Hanley, M. S. (2005). The Dialectics of Roosting Chickens: "Race" in U. S. Education. In S. A. Hughes (Ed.), What we still don't know about teaching race: how to talk about it in the classroom. (pp. i-xvi). New York: Edwin Mellen Press.

Helms, J. E. (1984). Toward a theoretical explanation of the effects of race on counseling: a Black and White model. The Counseling Psychologist, 12, 153-165.

Helms, J. E. (1992). A race is a nice thing to have: A guide to being a White person or understanding the white person in your life. KS: Content Communications. 
Johnson, S. D. (1987). Knowing that versus knowing how: Toward achievement expertise through multicultural training for counseling. The Counseling Psychologist, 15, 320-331.

Loewen, J. W. (2007). Lies my teacher told me: Everything your American history teacher got wrong. New York: Touchstone.

Robinsin, T. L. (1999). The intersections of identity. In A. Garrod, J. V Ward, T. L. Robinson, \& R. Kilkenny (Eds.), Souls looking back: Life stories of growing of Black. (pp. 85-98). New York: Routldege.

Utsey, S. O., \& Gernat, C. A., \& Bolden, M. A. (2002). Teaching racial identity development and racism awareness: Training in professional psychology programs. In G. Bernal, J. E. Trimble, A. K. Burlew, \& F. T. L. Leong (Eds.), Handbook of racial and ethnic minority psychology (pp. 147-166). Thousand Oaks, CA: Sage. 